Article

\title{
Promotional Effect of Ce on Iron-Based Catalysts for Selective Catalytic Reduction of $\mathrm{NO}$ with $\mathrm{NH}_{3}$
}

\author{
Xiaobo Wang ${ }^{1,2, *}$, Lei Zhang ${ }^{3}$, Shiguo Wu ${ }^{1,2}$, Weixin Zou ${ }^{1,2}$, Shuohan Yu ${ }^{1,2}$, Ye Shao ${ }^{1,2}$ and \\ Lin Dong ${ }^{1,2, *}$ \\ 1 Key Laboratory of Mesoscopic Chemistry of Ministry of Education School of Chemistry and \\ Chemical Engineering, Nanjing University, Nanjing 210093, China; 15062252586@163.com (S.W.); \\ zouweixin2011@163.com (W.Z.); yu061130159@163.com (S.Y.); sy_shaoye92@163.com (Y.S.) \\ 2 Jiangsu Key Laboratory of Vehicle Emissions Control, Center of Modern Analysis, Nanjing University, \\ Nanjing 210093, China \\ 3 School of Environmental and Chemical Engineering, Chongqing Three Gorges University, \\ Chongqing 404020, China; zhanglei58347387@163.com \\ * Correspondence: winstonwell@126.com (X.W.); donglin@nju.edu.cn (L.D.); \\ Tel.: +86-25-8359-2290 (X.W. \& L.D.); Fax: +86-25-8331-7761 (X.W. \& L.D.)
}

Academic Editor: Keith Hohn

Received: 16 May 2016; Accepted: 20 July 2016; Published: 26 July 2016

\begin{abstract}
A series of Fe-Ce-Ti catalysts were prepared via co-precipitation method to investigate the effect of doping $\mathrm{Ce}$ into Fe-Ti catalysts for selective catalytic reduction of $\mathrm{NO}$ with $\mathrm{NH}_{3}$. The NO conversion over Fe-Ce-Ti catalysts was considerably improved after Ce doping compared to that of Fe-Ti catalysts. The $\mathrm{Fe}(0.2)-\mathrm{Ce}(0.4)-\mathrm{Ti}$ catalysts exhibited superior catalytic activity to that of $\mathrm{Fe}(0.2)-\mathrm{Ti}$ catalysts. The obtained catalysts were characterized by $\mathrm{N}_{2}$ adsorption (BET), $X$-ray diffraction (XRD), temperature programmed reduction $\left(\mathrm{H}_{2}-\mathrm{TPR}\right)$, temperature programmed desorption ( $\left.\mathrm{NH}_{3}-\mathrm{TPD}\right)$, Fourier transform infrared (FT-IR) spectrophotometry, thermogravimetric analysis (TGA), and X-ray photoelectron spectroscopy (XPS). The data showed that the introduction of Ce results in higher surface area and better dispersion of active components on the catalyst surface and enhances the amount of surface acid sites. The interactions between Fe and Ce species were found to improve the redox ability of the catalyst, which promotes catalytic performance at low temperature. The XPS results revealed that $\mathrm{Fe}^{3+} / \mathrm{Fe}^{2+}$ and $\mathrm{Ce}^{4+} / \mathrm{Ce}^{3+}$ coexisted on the catalyst surface and that $\mathrm{Ti}$ was in $4+$ oxidation state on catalyst surface. Ce doping increased the atomic ratio of $\mathrm{Fe} / \mathrm{Ti}$ and $\mathrm{Ce} / \mathrm{Ti}$ and enhanced the surface adsorbed oxygen species. In addition, $\mathrm{Fe}(0.2)-\mathrm{Ce}(0.4)-\mathrm{Ti}$ catalyst also showed better tolerance to $\mathrm{H}_{2} \mathrm{O}$ and $\mathrm{SO}_{2}$ and up to $92 \% \mathrm{NO}$ conversion at $270{ }^{\circ} \mathrm{C}$ with 200 ppm SO 2 added over $25 \mathrm{~h}$, which suggests that it is a promising industrial catalyst for mid-low temperature $\mathrm{NH}_{3}$-selective catalytic reduction (SCR) reaction.
\end{abstract}

Keywords: SCR; denitration; catalytic activity; synergistic effect; $\mathrm{SO}_{2}$ resistance

\section{Introduction}

$\mathrm{NO}_{x}\left(\mathrm{NO}\right.$ and $\left.\mathrm{NO}_{2}\right)$, which is emitted primarily from power plants and automobile exhaust gases, is considered a major environmental pollutants and has garnered world-wide research attention due to its toxicity to the air and threat to human health [1,2]. Securing methods to effectively reduce $\mathrm{NO}_{x}$ emissions is a crucial endeavor. In recent years, a variety of methods have been developed to reduce $\mathrm{NO}_{x}$ emissions. Selective catalytic reduction (SCR) of $\mathrm{NO}_{x}$ with $\mathrm{NH}_{3}$ is often applied to remove $\mathrm{NO}_{x}$ from stationary sources, for example. The commercial catalysts typically used for SCR are $\mathrm{V}_{2} \mathrm{O}_{5} / \mathrm{TiO}_{2}$ or $\mathrm{V}_{2} \mathrm{O}_{5}-\mathrm{WO}_{3} / \mathrm{TiO}_{2}$ catalysts, which have high catalytic activity in temperatures from $300-400{ }^{\circ} \mathrm{C}[1,3]$. Unfortunately, there are several problems inherent to existing commercial catalysts such as the decline 
of $\mathrm{N}_{2}$ selectivity at high temperatures, the environmental toxicity of vanadium species, high conversion of $\mathrm{SO}_{2}$ to $\mathrm{SO}_{3}$, and the relatively narrow activity temperature window [2,3]. There is considerable and urgent demand for alternative catalysts for SCR applications, particularly those that are highly active, environmentally friendly, stable, and vanadium-free.

In recent years, a number of transition metal-containing catalysts, such as $\mathrm{FeO}_{x}, \mathrm{MnO}_{x}, \mathrm{CuO}_{x}$, and $\mathrm{CrO}_{x}$ have been developed as $\mathrm{NH}_{3}$-SCR catalysts. Among them, Fe-based catalysts have attracted special attention due to their excellent catalytic activity, nontoxicity, favorable $\mathrm{N}_{2}$ selectivity, and high hydrothermal stability [4-11]. Feng et al. [5], for example, found that the isolated $\mathrm{Fe}^{3+}$ species forms the main active sites in SCR reactions and that Fe/ZSM- 5 catalyst (prepared via the cauliflower-like morphology of ZSM-5 support) exhibits excellent SCR catalytic activity. Zhu et al. [6] reported that Al-Fe-SBA-15 catalysts synthesized by microwave methods exhibit up to $95 \% \mathrm{NO}_{x}$ conversion at about $360^{\circ} \mathrm{C}$. Compared to single-component catalysts, those with composite components possess improved catalytic activity due to the internal synergistic effect of the active species. Putluru et al. [7] found that $25 \mathrm{Mn} 0.75 \mathrm{Fe} 0.25 \mathrm{Ti}-\mathrm{DP}$ catalyst prepared by deposition precipitation (DP) has quite high SCR catalytic performance, with relative activity 26.9 times higher than a standard industrial-type VWTi catalyst at $175{ }^{\circ} \mathrm{C}$. Qi and Yang [8] found that $\mathrm{Mn}-\mathrm{Fe} / \mathrm{TiO}_{2}$ catalysts also have excellent catalytic activity, $\mathrm{N}_{2}$ selectivity, and high resistance to $\mathrm{SO}_{2}$ and $\mathrm{H}_{2} \mathrm{O}$. Zhou et al. [9] reported that $\mathrm{Fe}-\mathrm{Ce}-\mathrm{Mn} / \mathrm{ZSM}-5$ catalysts exhibit nearly $100 \% \mathrm{NO}$ conversion at $300{ }^{\circ} \mathrm{C}$ with a gas hourly space velocity (GHSV) of $30,000 \mathrm{~h}^{-1}$, and Zhang and $\mathrm{Qu}$ [10] found that $\mathrm{Fe}-\mathrm{CuO} x / \mathrm{ZSM}-5$ catalysts show higher catalytic activity than $\mathrm{FeO}_{x} / \mathrm{ZSM}-5$ or $\mathrm{CuO}_{x} / \mathrm{ZSM}-5$ catalysts. In short, the introduction of supplemental $\mathrm{Fe}$ ions as promoter is a very effective approach to enhancing the catalytic activity of iron-based catalysts.

Ceria $\left(\mathrm{CeO}_{2}\right)$, as a catalyst support or catalyst promoter, is of substantial interest to current researchers; it has been studied extensively due to its unique redox properties and oxygen storage capability [12-15]. It can store and release oxygen via the redox shift between $\mathrm{Ce}^{4+}$ and $\mathrm{Ce}^{3+}$. The transformation between the electrons and formation of oxygen vacancy generated by charge mismatching also leads to the formation of chemisorbed oxygen that benefits the SCR reaction [16]. It also can promote the oxidation of $\mathrm{NO}$ to $\mathrm{NO}_{2}$, which results in a "fast SCR" and further enhancement of the SCR reaction [15].

As described above, iron-based catalysts show excellent catalytic activity in terms of $\mathrm{NH}_{3}-\mathrm{SCR}$ reactions, and Ceria facilitates highly favorable catalytic performance in other metal oxides used as SCR catalysts due to its superior oxygen storage capacity and redox properties. The catalytic behavior of catalysts is closely dependent on the method by which they are prepared as well as their supporting materials and active species. When Ce is introduced to different catalysts (or the catalysts are prepared by different methods,) the resulting manifestations and promotion mechanisms differ. For Fe-Ce catalysts, recent studies have focused on co-precipitation preparation methods without support [17] or supported on $\mathrm{H}-\mathrm{B}$ zeolite [4], Beta [18], or $\mathrm{TiO}_{2}$ [19] via ion exchange or impregnation. There have been few reports, however, on the promotional effect of $\mathrm{Ce}$ on $\mathrm{Fe}$-Ti catalysts prepared via co-precipitation methods for the express purposes of $\mathrm{NO}$ reduction.

In this study, a series of $\mathrm{Fe}-\mathrm{Ce}-\mathrm{Ti}$ catalysts were prepared by co-precipitation technique and applied to $\mathrm{NH}_{3}-\mathrm{SCR}$ of NO. The catalytic performance of the prepared catalyst was systematically investigated and the effects of Ce on structural, surface, and catalytic properties were investigated using $\mathrm{N}_{2}$ physisorption, $\mathrm{X}$-ray diffraction (XRD), $\mathrm{H}_{2}$ temperature-programmed reduction $\left(\mathrm{H}_{2}-\mathrm{TPR}\right)$, and $\mathrm{NH}_{3}$ temperature-programmed desorption $\left(\mathrm{NH}_{3}\right.$-TPD), and $\mathrm{X}$-ray photoelectron spectroscopy (XPS). The $\mathrm{SO}_{2}$ and $\mathrm{H}_{2} \mathrm{O}$ resistance of the catalysts were also surveyed and the used catalysts were investigated using Fourier transform infrared (FT-IR) spectrophotometry and thermogravimetric analysis (TGA). 


\section{Results and Discussion}

\subsection{Catalytic Properties of Catalysts}

\subsubsection{Effect of Iron Loading on Catalytic Activity}

The effect of iron loading on Fe-Ti catalytic activity was investigated in the temperature range of $120-360{ }^{\circ} \mathrm{C}$. As shown in Figure 1, the NO conversion of catalysts was observed to be closely related to the amount of iron loading; catalytic activity was ranked by $\mathrm{Fe}(0.02)-\mathrm{Ti}<\mathrm{Fe}(0.05)-\mathrm{Ti}<$ $\mathrm{Fe}(0.1)-\mathrm{Ti}<\mathrm{Fe}(0.4)-\mathrm{Ti}<\mathrm{Fe}(0.2)-\mathrm{Ti}$. For the $\mathrm{Fe}(0.02)-\mathrm{Ti}$ catalysts, less than $20 \% \mathrm{NO}$ conversion was obtained at $120^{\circ} \mathrm{C}$ and the highest $\mathrm{NO}$ conversion was only $82 \%$ at $360^{\circ} \mathrm{C}$. The NO conversion of the catalysts increased considerably as the iron load increased from 0.02 to 0.2 . The $\mathrm{Fe}(0.2)-\mathrm{Ti}$ catalysts showed the highest $\mathrm{NO}$ conversion over the whole reaction temperature range: more than $85 \% \mathrm{NO}$ conversion from 270 to $360^{\circ} \mathrm{C}$. When the iron loading further increased to 0.4 , the catalytic activity of $\mathrm{Fe}(0.4)-\mathrm{Ti}$ catalysts decreased slightly. The $\mathrm{Fe}(0.2)-\mathrm{Ti}$ catalysts exhibited the best $\mathrm{NO}$ conversion of all the samples; the optimal of Fe/Ti molar ratio was 0.2 .

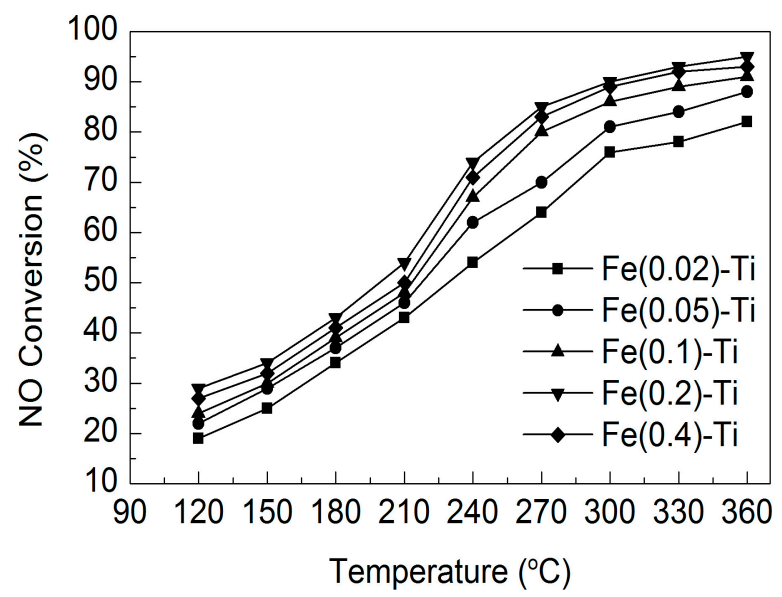

Figure 1. NO conversion over various Fe-Ti catalysts. Reaction conditions: $[\mathrm{NO}]=\left[\mathrm{NH}_{3}\right]=500 \mathrm{ppm}$, $\left[\mathrm{O}_{2}\right]=5$ vol. $\%, \mathrm{~N}_{2}$ balance, and gas hourly space velocity $(\mathrm{GHSV})=90,000 \mathrm{~h}^{-1}$.

\subsubsection{Promotional Effect of Ce on Catalytic Activity}

Because the optimal $\mathrm{Fe} / \mathrm{Ti}$ molar ratio was found to be 0.2 , we next prepared a series of $\mathrm{Fe}(0.2)-\mathrm{Ce}(x)-\mathrm{Ti}$ catalysts and ran comparisons among $\mathrm{Fe}(0.2)-\mathrm{Ti}$ and $\mathrm{Fe}(0.2)-\mathrm{Ce}(x)-\mathrm{Ti}$ catalysts to investigate the promotional effect of Ce doping on catalytic activity. Figure 2 shows the NO conversion of various $\mathrm{Fe}(0.2)-\mathrm{Ce}(x)-\mathrm{Ti}$ catalysts with different $\mathrm{Ce} / \mathrm{Ti}$ molar ratios under different GHSVs as a function of reaction temperature. As shown in Figure 2a, with a GHSV of 90,000 $\mathrm{h}^{-1}$, the Fe(0.2)-Ti catalysts showed much poorer catalytic activity than others throughout the temperature range. By contrast, after Ce doping, the NO conversion of various $\mathrm{Fe}(0.2)-\mathrm{Ce}(x)-\mathrm{Ti}$ catalysts increased remarkably as temperature increased; catalytic activity was ranked by $\mathrm{Fe}(0.2)-\mathrm{Ce}(0.4)-\mathrm{Ti}>\mathrm{Fe}(0.2)-\mathrm{Ce}(0.2)-\mathrm{Ti}>$ $\mathrm{Fe}(0.2)-\mathrm{Ce}(0.05)-\mathrm{Ti}>\mathrm{Fe}(0.2)-\mathrm{Ce}(0.8)-\mathrm{Ti}>\mathrm{Fe}(0.2)-\mathrm{Ce}(0.02)-\mathrm{Ti}>\mathrm{Fe}(0.2)-\mathrm{Ti}$. The Fe (0.2)-Ce(0.4)-Ti catalysts showed optimal catalytic activity, yielding more than $94 \%$ NO conversion in the temperature range of $240-360^{\circ} \mathrm{C}$. The catalytic activity of $\mathrm{Fe}(0.2)-\mathrm{Ce}(0.8)-\mathrm{Ti}$ markedly decreased as the Ce-Ti molar ratio further increased to 0.8 , especially at low temperatures. Under the GHSV of $180,000 \mathrm{~h}^{-1}$ (shown in Figure $2 b)$, the de-NO efficiency over various $\mathrm{Fe}(0.2)-\mathrm{Ce}-\mathrm{Ti}$ catalysts increased with the increasing reaction temperature. In the whole reaction temperature range, the $\mathrm{Fe}(0.2)-\mathrm{Ce}(0.4)-\mathrm{Ti}$ still exhibited the highest activity and the sequence of catalysts activities were basically consistent with that at GHSV of 90,000 $\mathrm{h}^{-1}$. Based on these results, we confirmed that doping Ce into Fe(0.2)-Ti catalysts is indeed 
beneficial to improving the catalytic activity for $\mathrm{NH}_{3}-\mathrm{SCR}$ reactions. The optimal Ce-Ti molar ratio was 0.4 .
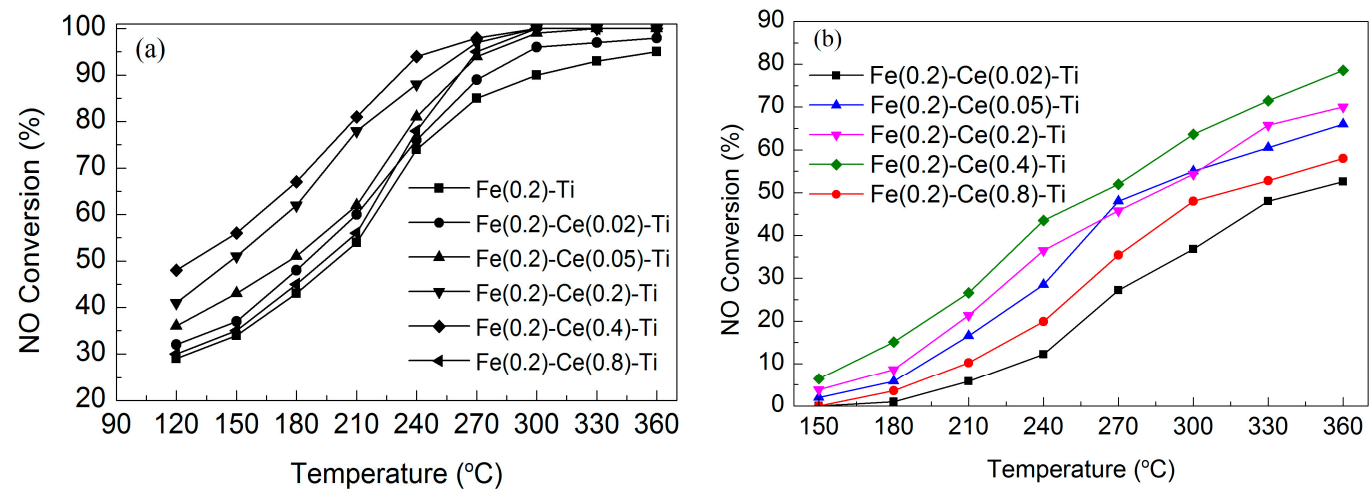

Figure 2. NO conversion of various Fe-Ce-Ti catalysts at different GHSVs: (a) GHSV $=90,000 \mathrm{~h}^{-1}$ and (b) $\mathrm{GHSV}=180,000 \mathrm{~h}^{-1}$. Reaction conditions: $[\mathrm{NO}]=\left[\mathrm{NH}_{3}\right]=500 \mathrm{ppm},\left[\mathrm{O}_{2}\right]=5$ vol. $\%, \mathrm{~N}_{2}$ balance.

The NO conversion results of $\mathrm{Fe}(0.2)-\mathrm{Ti}, \mathrm{Ce}(0.4)-\mathrm{Ti}$, and $\mathrm{Fe}(0.2)-\mathrm{Ce}(0.4)-\mathrm{Ti}$ catalysts are shown in Figure 3. NO conversion increased for all catalysts as reaction temperature increased. Compared to the $\mathrm{Fe}(0.2)-\mathrm{Ti}, \mathrm{Ce}(0.4)-\mathrm{Ti}$ catalysts, which were comprised of single active components, the $\mathrm{Fe}(0.2)-\mathrm{Ce}(0.4)-\mathrm{Ti}$ catalysts exhibited superior catalytic activity. In effect, binary-component catalysts had the best catalytic activity-there was a synergistic catalytic effect of active species in the SCR reaction.

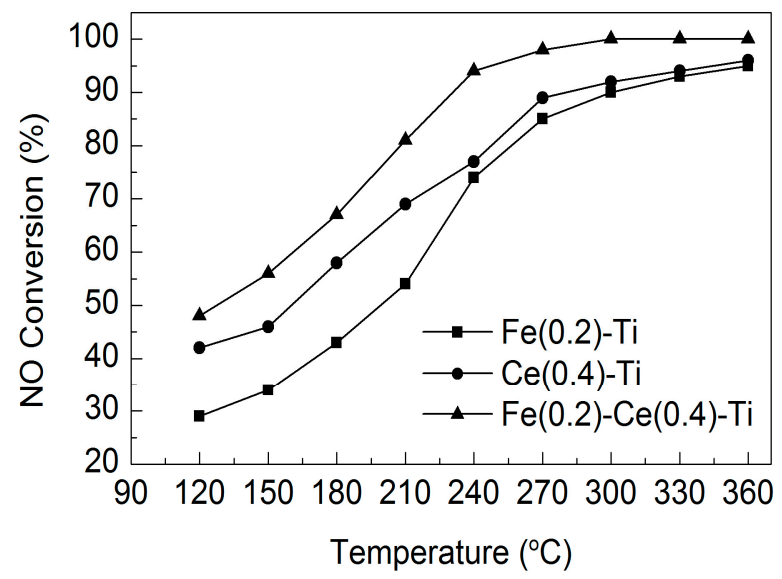

Figure 3. $\mathrm{NO}$ conversion over $\mathrm{Fe}(0.2)-\mathrm{Ti}, \mathrm{Ce}(0.4)-\mathrm{Ti}$, and $\mathrm{Fe}(0.2)-\mathrm{Ce}(0.4)-\mathrm{Ti}$ catalysts. Reaction conditions: $[\mathrm{NO}]=\left[\mathrm{NH}_{3}\right]=500 \mathrm{ppm},\left[\mathrm{O}_{2}\right]=5 \mathrm{vol} . \%, \mathrm{~N}_{2}$ balance, and GHSV $=90,000 \mathrm{~h}^{-1}$.

\subsubsection{NO Oxidation Characteristics}

The oxidation activities of $\mathrm{NO}$ to $\mathrm{NO}_{2}$ over $\mathrm{Fe}(0.2)-\mathrm{Ti}$ and $\mathrm{Fe}(0.2)-\mathrm{Ce}(0.4)-\mathrm{Ti}$ catalysts were investigated in the temperature range of $120-360{ }^{\circ} \mathrm{C}$ as shown in Figure 4. Clearly, the oxidation activity of $\mathrm{NO}$ to $\mathrm{NO}_{2}$ was limited for $\mathrm{Fe}(0.2)-\mathrm{Ti}$ catalysts at low temperature but was enhanced as reaction temperature increased. For the $\mathrm{Fe}(0.2)-\mathrm{Ce}(0.4)-\mathrm{Ti}$ catalysts, $\mathrm{NO}$ oxidation became stronger after Ce doping. Based on previous studies [8,20,21], the reaction rate of $\mathrm{NH}_{3}$ with $\mathrm{NO}+\mathrm{NO}_{2}$ is higher than that with $\mathrm{NO}$ only due to the "fast SCR" reaction mentioned in the Introduction. Our $\mathrm{Fe}(0.2)-\mathrm{Ce}(0.4)-\mathrm{Ti}$ catalysts did exhibit stronger oxidation activity of $\mathrm{NO}$ to $\mathrm{NO}_{2}$, i.e., higher catalytic activity than other catalysts. Possible reasons for the enhanced oxidation activity of $\mathrm{NO}$ to $\mathrm{NO}_{2}$ by $\mathrm{Ce}$ doping (as well as the results of $\mathrm{H}_{2}$-TPR and XPS) are discussed below. 


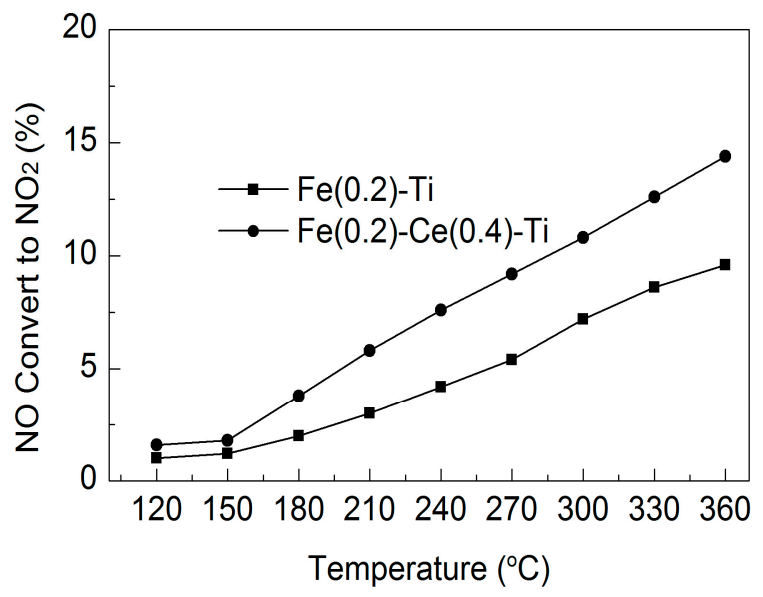

Figure 4. Oxidation activity of $\mathrm{NO}$ to $\mathrm{NO}_{2}$ by $\mathrm{O}_{2}$ on $\mathrm{Fe}(0.2)-\mathrm{Ti}$ and $\mathrm{Fe}(0.2)-\mathrm{Ce}(0.4)-\mathrm{Ti}$ catalysts. Reaction conditions: $[\mathrm{NO}]=500 \mathrm{ppm},\left[\mathrm{O}_{2}\right]=5$ vol. $\%, \mathrm{~N}_{2}$ balance, and GHSV $=90,000 \mathrm{~h}^{-1}$.

\subsection{Catalyst Characterization}

\subsubsection{BET Results}

$\mathrm{N}_{2}$ physisorption was conducted to investigate the physical properties of the catalysts described above. The results are shown in Table 1. The BET surface area and pore volume of $\mathrm{Fe}(0.2)-\mathrm{Ti}$ catalysts were only $76.04 \mathrm{~cm}^{2} \cdot \mathrm{g}^{-1}$ and $0.2783 \mathrm{~cm}^{3} \cdot \mathrm{g}^{-1}$, respectively. After Ce doping, the BET surface area and pore volume increased; when the $\mathrm{Ce} / \mathrm{Ti}$ molar ratio increased to 0.2 and 0.4 , the BET surface area and pore volume of catalysts increased to $210.85 \mathrm{~cm}^{2} \cdot \mathrm{g}^{-1}, 0.6094 \mathrm{~cm}^{3} \cdot \mathrm{g}^{-1}$ and $146.82 \mathrm{~cm}^{2} \cdot \mathrm{g}^{-1}$, $0.6456 \mathrm{~cm}^{3} \cdot \mathrm{g}^{-1}$, respectively. Further increase in Ce/Ti molar ratio to 0.8 caused the BET surface area and pore volume to decrease slightly but remain higher than that of $\mathrm{Fe}(0.2)-\mathrm{Ti}$ catalysts. These results clearly indicated that Ce doping enhanced the dispersion of active metal oxides and thus increased the specific area and pore volume of the catalysts (as further confirmed by the XRD results discussed below). Variations in catalytic activity were basically consistent with the surface area variations of the catalysts, especially the pore volume, suggesting that the surface area and pore volume of catalysts are closely related with their catalytic activity. Larger surface area and pore volume provide more active sites for the SCR reaction and thus adsorb more reactant molecules, which promote the reaction and result in the favorable catalytic activity we observed.

Table 1. Physical properties of various catalysts.

\begin{tabular}{ccc}
\hline Sample & BET $\left(\mathbf{c m}^{\mathbf{2}} \cdot \mathbf{g}^{-\mathbf{1}} \mathbf{)}\right.$ & Pore Volume $\mathbf{~} \mathbf{~}^{\mathbf{3}} \cdot \mathbf{g}^{\mathbf{- 1}} \mathbf{)}$ \\
\hline $\mathrm{Fe}(0.2)-\mathrm{Ti}$ & 76.04 & 0.2783 \\
$\mathrm{Fe}(0.2)-\mathrm{Ce}(0.02)-\mathrm{Ti}$ & 117.42 & 0.2611 \\
$\mathrm{Fe}(0.2)-\mathrm{Ce}(0.05)-\mathrm{Ti}$ & 141.75 & 0.3219 \\
$\mathrm{Fe}(0.2)-\mathrm{Ce}(0.2)-\mathrm{Ti}$ & 210.85 & 0.6094 \\
$\mathrm{Fe}(0.2)-\mathrm{Ce}(0.4)-\mathrm{Ti}$ & 146.82 & 0.6456 \\
$\mathrm{Fe}(0.2)-\mathrm{Ce}(0.8)-\mathrm{Ti}$ & 105.18 & 0.3964 \\
\hline
\end{tabular}

\subsubsection{XRD Results}

Figure 5 shows XRD patterns of different $\mathrm{Fe}(0.2)-\mathrm{Ce}(x)$-Ti catalysts $(x=0,0.02,0.05,0.2,0.4,0.8)$. Apparent diffraction peaks corresponding to crystallite $\mathrm{Fe}_{2} \mathrm{O}_{3}$ and $\mathrm{TiO}_{2}$ were observed in the $\mathrm{Fe}(0.2)-\mathrm{Ti}$ catalysts without $\mathrm{Ce}$ doping. After $\mathrm{Ce}$ doping $(\mathrm{Ce} / \mathrm{Ti}$ molar ratio $=0.02)$, conversely, the intensity of $\mathrm{Fe}_{2} \mathrm{O}_{3}$ and $\mathrm{TiO}_{2}$ diffraction peaks decreased and no visible peaks attributed to Ce were detected, indicating that the growth of crystallite $\mathrm{Fe}_{2} \mathrm{O}_{3}$ and $\mathrm{TiO}_{2}$ was strongly suppressed by the introduction of Ce. With further increase in Ce load (Ce/Ti molar ratio $=0.05,0.2,0.4,0.8)$, the intensity of 
diffraction peaks gradually decreased until no visible $\mathrm{Fe}, \mathrm{Ce}$, or Ti species phases could be observed, suggesting that the $\mathrm{Fe}, \mathrm{Ce}$, and Ti oxides were highly dispersed on the catalyst surface or at least that its particle size was outside the XRD detection limit $[8,19]$. In brief, these results showed that Ce doping inhibits the crystallinity of metal oxides and enhances the dispersion of active species on the catalyst surface, which is beneficial as far as increasing the surface area and active sites to promote catalytic activity in SCR reactions $[4,14]$. This is consistent with the BET and catalytic property testing results discussed above.

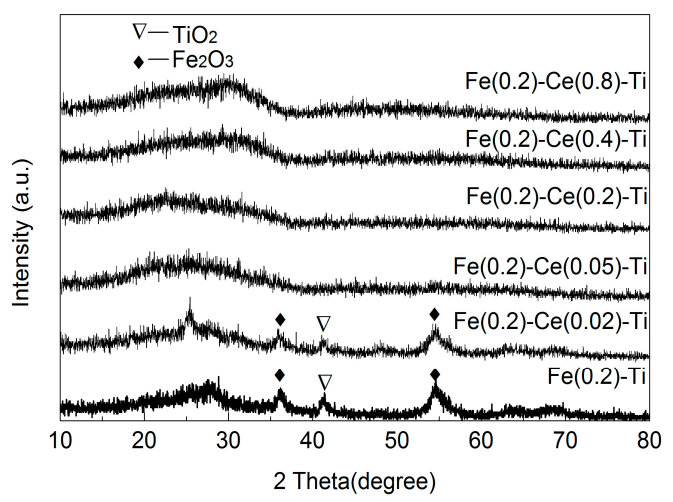

Figure 5. XRD patterns of $\mathrm{Fe}(0.2)-\mathrm{Ce}(x)-\mathrm{Ti}$ catalysts $(x=0,0.02,0.05,0.2,0.4,0.8)$.

\subsection{3. $\mathrm{H}_{2}$-TPR Results}

It is commonly accepted that the redox property of catalysts is an important factor in terms of SCR reactions, so we utilized $\mathrm{H}_{2}$-TPR characterization to investigate the effect of Ce doping on catalyst redox properties (Figure 6). For Fe(0.2)-Ti catalysts, three deconvoluted reduction peaks were displayed in the temperature range of $200-800{ }^{\circ} \mathrm{C}$, reflecting the reductive nature of the iron species. The reduction peaks centered at 354 and $394^{\circ} \mathrm{C}$, which indicated greater intensity, can be assigned to the reduction of $\mathrm{Fe}_{2} \mathrm{O}_{3}$ to $\mathrm{Fe}^{2+}[5,22,23]$. The splitting signal we detected may have been due to the various interactions of $\mathrm{Fe}$ with $\mathrm{Ti}$ or the reduction of $\mathrm{Fe}^{3+}$ located in different sites within the catalyst structure [22]. The third reduction peaks, which showed less intensity and appeared at $778{ }^{\circ} \mathrm{C}$, were attributed to the reduction of $\mathrm{Fe}^{2+}$ to $\mathrm{Fe}^{0}[5,19]$. After Ce doping, the $\mathrm{H}_{2}-\mathrm{TPR}$ profile of $\mathrm{Fe}(0.2)-\mathrm{Ce}(0.4)-\mathrm{Ti}$ catalysts showed enhanced reduction peaks. The reduction peaks at $370{ }^{\circ} \mathrm{C}$ and $402{ }^{\circ} \mathrm{C}$, which were similar to that of $\mathrm{Fe}(0.2)$-Ti catalysts, were attributed to the reduction of $\mathrm{Fe}_{2} \mathrm{O}_{3}$ to $\mathrm{Fe}^{2+}$ while the peaks at $466^{\circ} \mathrm{C}$ can be regarded as the reduction of the uppermost layer of $\mathrm{Ce}^{4+}$ to $\mathrm{Ce}^{3+}[23-25]$. The broad reduction peaks at $628^{\circ} \mathrm{C}$ can potentially be ascribed to the reduction of $\mathrm{Fe}^{2+}$ to $\mathrm{Fe}^{0}$ and the deeper interior of $\mathrm{CeO}_{2}$ and bulk $\mathrm{CeO}_{2}[4,25,26]$.

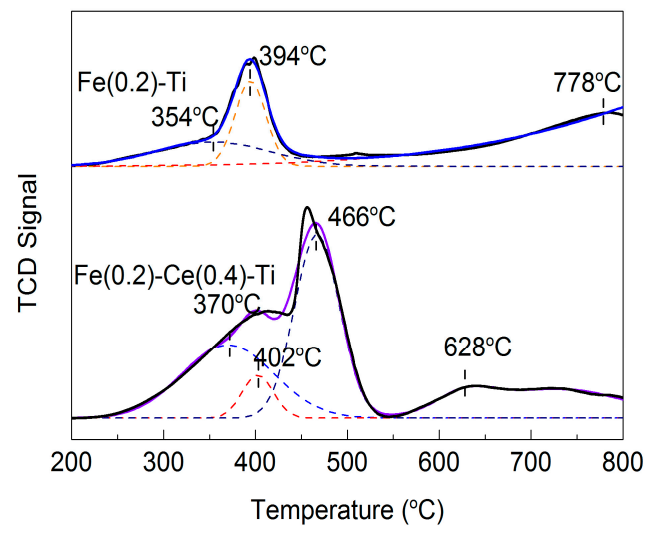

Figure 6. $\mathrm{H}_{2}$-TPR profiles for $\mathrm{Fe}(0.2)-\mathrm{Ti}$ and $\mathrm{Fe}(0.2)-\mathrm{Ce}(0.4)-\mathrm{Ti}$ catalysts. 
Compared to the $\mathrm{H}_{2}$-TPR results of $\mathrm{Fe}(0.2)-\mathrm{Ti}$ and $\mathrm{Fe}(0.2)-\mathrm{Ce}(0.4)-\mathrm{Ti}$ catalysts, the total reduction peak areas of $\mathrm{Fe}(0.2)-\mathrm{Ce}(0.4)-\mathrm{Ti}$ catalysts were much larger than those of $\mathrm{Fe}(0.2)-\mathrm{Ti}$ catalysts, especially at low temperatures $\left(<550^{\circ} \mathrm{C}\right)$. This indicated that the $\mathrm{Fe}(0.2)-\mathrm{Ce}(0.4)-\mathrm{Ti}$ catalysts had more reductive species and that more chemisorbed oxygen formed on the catalyst surface after Ce doping (Table 2), which benefited the SCR reaction $[19,27,28]$. In addition to the enhanced reduction peak areas of the catalyst, the reduction peak of $\mathrm{Fe}^{2+}$ to $\mathrm{Fe}^{0}$ shifted to the lower temperature region-this reflects a strong interaction between Fe and Ce species (as further confirmed by the XPS results shown below) [4]. Considering also the $\mathrm{NO}+\mathrm{O}_{2}$ and $\mathrm{NO}+\mathrm{NH}_{3}+\mathrm{O}_{2}$ reaction results, this may have been due to the fact that the improved redox properties of $\mathrm{Fe}(0.2)-\mathrm{Ce}(0.4)-\mathrm{Ti}$ catalysts favored the occurrence of a fast SCR reaction, thus enhancing the $\mathrm{NO}$ conversion of $\mathrm{Fe}(0.2)-\mathrm{Ce}(0.4)-\mathrm{Ti}$ catalysts [29].

Table 2. XPS results of various catalysts.

\begin{tabular}{|c|c|c|c|c|c|c|c|c|c|}
\hline Catalyst & $\mathrm{Fe}$ & $\mathrm{Ce}$ & $\mathrm{Ti}$ & $\mathbf{O}$ & $\mathrm{Fe} / \mathrm{Ti}$ & $\mathrm{Ce} / \mathrm{Ti}$ & $\begin{array}{c}\mathrm{Fe}^{3+} /\left(\mathrm{Fe}^{2+}+\right. \\
\left.\mathrm{Fe}^{3+}\right)(\%)\end{array}$ & $\mathrm{Ce}^{4+} / \mathrm{Ce}^{3+}$ & $\begin{array}{c}\mathrm{O} \beta /(\mathrm{O} \alpha+ \\
\mathbf{O} \beta)(\%)\end{array}$ \\
\hline $\mathrm{Fe}(0.2)-\mathrm{Ti}$ & 4.60 & - & 17.42 & 53.66 & 0.264 & - & 39.49 & - & 5.9 \\
\hline $\mathrm{Ce}(0.4)-\mathrm{Ti}$ & - & 1.94 & 17.75 & 51.21 & - & 0.109 & - & 2.23 & 8.5 \\
\hline $\mathrm{Fe}(0.2)-\mathrm{Ce}(0.4)-\mathrm{Ti}$ & 3.47 & 4.50 & 11.44 & 53.07 & 0.303 & 0.393 & 29.22 & 3.43 & 20.1 \\
\hline
\end{tabular}

\subsection{4. $\mathrm{NH}_{3}$-TPD Results}

$\mathrm{NH}_{3}$-TPD analysis was conducted to evaluate the effect of Ce doping on the surface acidity of the catalysts. The results are shown in Figure 7. The shape of the $\mathrm{Fe}(0.2)-\mathrm{Ti}$ and $\mathrm{Fe}(0.2)-\mathrm{Ce}(0.4)-\mathrm{Ti}$ catalyst $\mathrm{NH}_{3}$-TPD curves were similar, and the TPD curves both could be fitted into two peaks. The peaks of $\mathrm{Fe}(0.2)-\mathrm{Ti}$ and $\mathrm{Fe}(0.2)-\mathrm{Ce}(0.4)-\mathrm{Ti}$ catalysts centered at 204 and $198{ }^{\circ} \mathrm{C}$, respectively, were attributed to $\mathrm{NH}_{3}$ adsorption bounded to weak acid sites while peaks centered at 311 and $286^{\circ} \mathrm{C}$ were ascribed to $\mathrm{NH}_{3}$ adsorption from medium and strong acid sites [1,23,30]. Compared to the TPD curves of $\mathrm{Fe}(0.2)-\mathrm{Ti}$ and $\mathrm{Fe}(0.2)-\mathrm{Ce}(0.4)-\mathrm{Ti}$ catalysts, the peak area significantly increased after the $\mathrm{Ce}$ doping. This indicated that $\mathrm{Ce}$ doping enhanced the amount of acid sites over the $\mathrm{Fe}(0.2)-\mathrm{Ce}(0.4)-\mathrm{Ti}$ catalysts due to the increase in specific area and new acid sites provided by $\mathrm{Ce}$, both of which favored the SCR reaction.

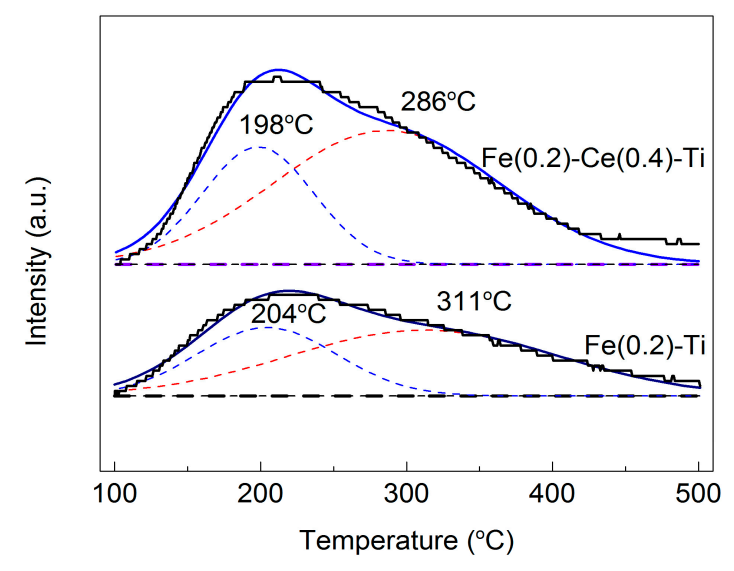

Figure 7. $\mathrm{NH}_{3}-\mathrm{TPD}$ results of $\mathrm{Fe}(0.2)-\mathrm{Ti}$ and $\mathrm{Fe}(0.2)-\mathrm{Ce}(0.4)-\mathrm{Ti}$ catalysts.

\subsubsection{XPS Results}

XPS measurement was carried out to observe the valence state and element content on catalyst surfaces. The photoelectron spectra of $\mathrm{Fe} 2 \mathrm{p}, \mathrm{Ce} 3 \mathrm{~d}$, and $\mathrm{O} 1 \mathrm{~s}$ are shown in Figure 8; the surface atomic concentrations, ratios of $\mathrm{Fe}^{3+} /\left(\mathrm{Fe}^{2+}+\mathrm{Fe}^{3+}\right)$ and $\mathrm{Ce}^{4+} / \mathrm{Ce}^{3+}$, and different oxygen species obtained via peak fitting are summarized in Table 2. 

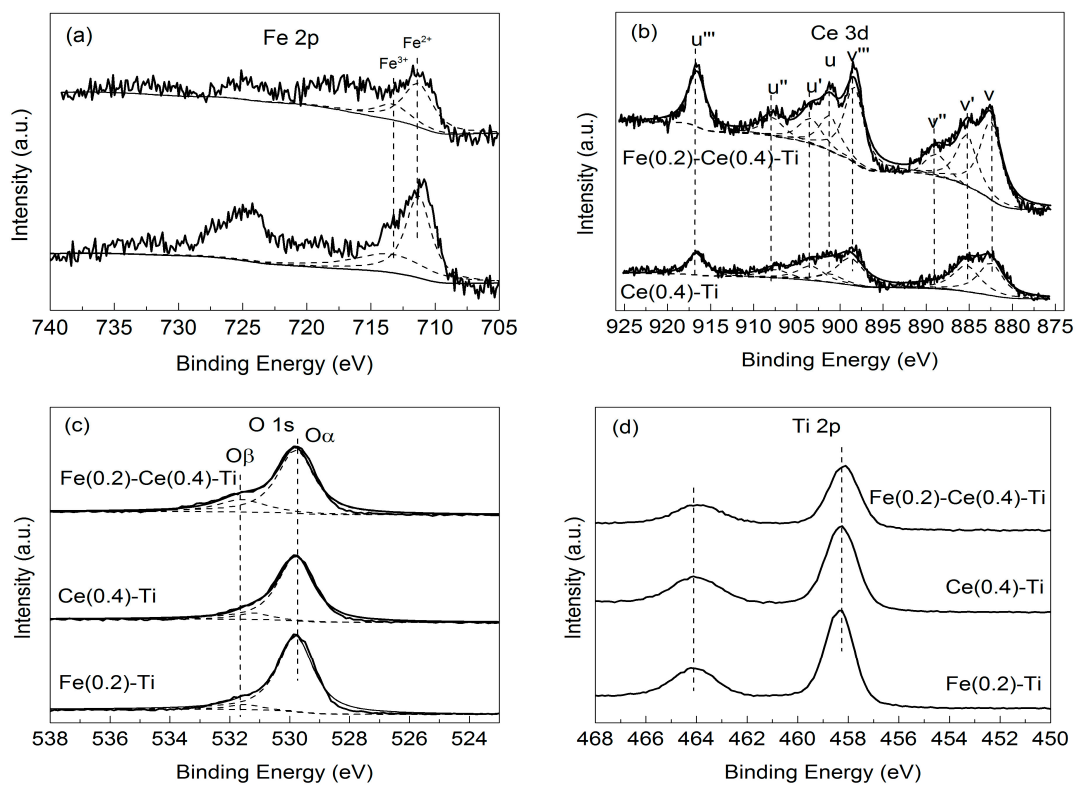

Figure 8. XPS spectra of (a) Fe 2p, (b) Ce 3d, (c) O 1s and (d) Ti $2 p$ for Fe(0.2)-Ti, Ce(0.4)-Ti and $\mathrm{Fe}(0.2)-\mathrm{Ce}(0.4)-\mathrm{Ti}$ catalyst.

The results of Fe $2 \mathrm{p}$ spectra for $\mathrm{Fe}(0.2)-\mathrm{Ti}$ and $\mathrm{Fe}(0.2)-\mathrm{Ce}(0.4)-\mathrm{Ti}$ catalysts are displayed in Figure $8 \mathrm{a}$. The binding energies of $\mathrm{Fe} 2 \mathrm{p}_{3 / 2}$ for $\mathrm{Fe}(0.2)-\mathrm{Ti}$ and $\mathrm{Fe}(0.2)-\mathrm{Ce}(0.4)-\mathrm{Ti}$ catalysts were both located at about $711.5 \mathrm{eV}$ and could be separated into two peaks corresponding to the iron in $\mathrm{Fe}^{2+}$ and $\mathrm{Fe}^{3+}$, respectively [4,5]. This observation suggested that $\mathrm{Fe}^{2+}$ and $\mathrm{Fe}^{3+}$ coexisted on the surface of the two catalysts. The relative contents of $\mathrm{Fe}^{2+}$ and $\mathrm{Fe}^{3+}$ were calculated and the ratios of $\mathrm{Fe}^{3+} /\left(\mathrm{Fe}^{2+}+\mathrm{Fe}^{3+}\right)$ were summarized as listed in Table 2, where it the ratio of $\mathrm{Fe}^{3+} /\left(\mathrm{Fe}^{2+}+\mathrm{Fe}^{3+}\right)$ for $\mathrm{Fe}(0.2)-\mathrm{Ti}$ catalyst is reported as $39.49 \%$ but only $29.22 \%$ for $\mathrm{Fe}(0.2)-\mathrm{Ce}(0.4)-\mathrm{Ti}$ catalyst. In effect, Ce doping decreased the relative percentage of $\mathrm{Fe}^{3+}$ species on the catalyst surface. The $\mathrm{Fe} / \mathrm{Ti}$ atomic ratio for $\mathrm{Fe}(0.2)-\mathrm{Ti}$ catalyst was 0.264; after Ce doping, it increased to 0.303. This indicates that there was a synergistic effect between $\mathrm{Fe}$ and $\mathrm{Ce}$ and that $\mathrm{Ce}$ doping promoted the accumulation of $\mathrm{Fe}$ on the catalyst surface.

As listed in Table 2, the proportions of $\mathrm{Fe}^{3+}$ and $\mathrm{Ce}^{3+}$ both decreased after Ce doping while the content of surface adsorbed oxygen increased. Moreover, compared to the binding energy (BE) values of $\mathrm{Fe} 2 \mathrm{p}$ for $\mathrm{Fe}(0.2)-\mathrm{Ti}$ catalyst, the BE values of $\mathrm{Fe} 2 \mathrm{p}$ for $\mathrm{Fe}(0.2)-\mathrm{Ce}(0.4)-\mathrm{Ti}$ catalyst shifted to lower values. These results can likely be attributed to the synergistic interaction of $\mathrm{Fe}$ and $\mathrm{Ce}$ via redox equilibrium of $\mathrm{Fe}^{3+}+\mathrm{Ce}^{3+} \leftrightarrow \mathrm{Fe}^{2+}+\mathrm{Ce}^{4+}$ [28]. The redox couples between $\mathrm{Fe}^{3+} / \mathrm{Fe}^{2+}$ and $\mathrm{Ce}^{4+} / \mathrm{Ce}^{3+}$ may have enhanced the redox cycle to promote the formation of oxygen vacancies, ultimately benefiting the formation of surface adsorbed oxygen [16].

Figure $8 \mathrm{~b}$ displays the Ce $3 \mathrm{~d}$ XPS spectra of the $\mathrm{Ce}(0.4)-\mathrm{Ti}$ and $\mathrm{Fe}(0.2)-\mathrm{Ce}(0.4)-\mathrm{Ti}$ catalysts. The bands labeled $u$ and $v$ were attributed to $3 d_{3 / 2}$ and $3 d_{5 / 2}$, respectively; the bands labeled $u^{\prime \prime}, v^{\prime \prime}, u^{\prime \prime \prime}$, and $\mathrm{v}^{\prime \prime \prime}$ were ascribed to $\mathrm{Ce}^{4+}$, while those labeled $\mathrm{u}^{\prime}$ and $\mathrm{v}^{\prime}$ were assigned to $\mathrm{Ce}^{3+}[29]$. These results suggested that both $\mathrm{Ce}^{4+}$ and $\mathrm{Ce}^{3+}$ coexisted on the surface of catalyst. The ratios of $\mathrm{Ce}^{4+} / \mathrm{Ce}^{3+}$ for $\mathrm{Ce}(0.4)-\mathrm{Ti}$ and $\mathrm{Fe}(0.2)-\mathrm{Ce}(0.4)-\mathrm{Ti}$ catalysts as-calculated via peak area integration were 2.23 and 3.43, respectively (Table 2). This demonstrates that the $\mathrm{Ce}^{4+}$ oxidation state was the dominant state of $\mathrm{Ce}$ on the surface of the catalysts. Combined with the catalytic property results shown in Figure 3, the coexistence of $\mathrm{Ce}^{4+}$ and $\mathrm{Ce}^{3+}$ on the surface catalyst enabled the process of oxygen storage and release, which was beneficial to the oxidation of $\mathrm{NO}$ to $\mathrm{NO}_{2}$ and generated a fast $\mathrm{SCR}$ reaction; these factors altogether enhanced the catalytic activity in SCR [13]. The concentration of Ce for Ce(0.4)-Ti was only $1.94 \%$ but was $4.50 \%$ for $\mathrm{Fe}(0.2)-\mathrm{Ce}(0.4)-\mathrm{Ti}$ catalyst. The greatly increased concentration of Ce on the catalyst surface further verifies that there was interaction between $\mathrm{Fe}$ and $\mathrm{Ce}$, which promoted the migration of Ce from the body to the surface of the catalyst. 
The XPS spectra of $\mathrm{O} 1 \mathrm{~s}$ for the $\mathrm{Fe}(0.2)-\mathrm{Ti}, \mathrm{Ce}(0.4)-\mathrm{Ti}$, and $\mathrm{Fe}(0.2)-\mathrm{Ce}(0.4)-\mathrm{Ti}$ catalysts are shown in Figure $8 \mathrm{c}$. The $\mathrm{O} 1 \mathrm{~s}$ spectra of the three catalysts were all easily fitted with two peaks: the peak centered at about $529.8 \mathrm{eV}$ (denoted as $\mathrm{O} \alpha$ ) corresponds to lattice oxygen while the peak around $531.5 \mathrm{eV}$ (denoted as $\mathrm{OB}$ ) can be assigned to surface adsorbed oxygen species [28]. The ratios of $\mathrm{OB} /(\mathrm{O} \alpha+\mathrm{OB})$ were $5.9 \%, 8.5 \%$ and $20.1 \%$, respectively, for the $\mathrm{Fe}(0.2)-\mathrm{Ti}, \mathrm{Ce}(0.4)-\mathrm{Ti}$ and $\mathrm{Fe}(0.2)-\mathrm{Ce}(0.4)-\mathrm{Ti}$ catalysts; clearly, the $\mathrm{Fe}(0.2)-\mathrm{Ce}(0.4)-\mathrm{Ti}$ catalyst exhibited the highest $\mathrm{O} /(\mathrm{O} \alpha+\mathrm{OB})$ ratio. More surface adsorbed oxygen species were formed on the surface of the $\mathrm{Fe}(0.2)-\mathrm{Ce}(0.4)-\mathrm{Ti}$ catalyst, which contributed to the oxidation of $\mathrm{NO}$ to $\mathrm{NO}_{2}$ and caused the fast SCR reaction. According to these and the results shown in Figures 3 and 4, the synergetic interaction between Fe and Ce activated more $\mathrm{O}_{2}$ molecules to react with $\mathrm{NO}$ and thus enhanced the SCR quality due to the fast SCR reaction.

Figure $8 \mathrm{~d}$ shows the XPS spectra of Ti $2 \mathrm{p}$ for the three catalysts, all of which displayed two peaks (Ti $2 \mathrm{p}_{3 / 2}$ and Ti $2 \mathrm{p}_{1 / 2}$ ). The binding energies of Ti $2 \mathrm{p}_{3 / 2}$ and Ti $2 \mathrm{p}_{1 / 2}$ for the three catalysts were all centered at about 458.4 and $464.1 \mathrm{eV}$, respectively, indicating that Ti was in 4+ oxidation state on the catalyst surface $[31,32]$. Further, the binding energies of Ti $2 p$ remained practically unchanged, providing more evidence that the increased $\mathrm{Ce}^{4+}$ was due to the synergistic interaction of $\mathrm{Fe}$ and $\mathrm{Ce}$ species via redox equilibrium of $\mathrm{Fe}^{3+}+\mathrm{Ce}^{3+} \leftrightarrow \mathrm{Fe}^{2+}+\mathrm{Ce}^{4+}$ and that the synergistic effect between $\mathrm{Fe}$ and Ce species was dominant.

\subsection{Influence of $\mathrm{SO}_{2}$ and $\mathrm{H}_{2} \mathrm{O}$ on SCR Activity of Catalysts}

It must be noted that there are traces of $\mathrm{SO}_{2}$ remaining in the flue gases even after desulfurization, because the catalyst may be deactivated in the presence of $\mathrm{SO}_{2}$. Therefore, it is of great importance to investigate the influence of $\mathrm{SO}_{2}$ on the catalytic activity of catalyst [33].

The influence of $\mathrm{SO}_{2}$ on catalytic activity of $\mathrm{Fe}(0.2)-\mathrm{Ti}$ and $\mathrm{Fe}(0.2)-\mathrm{Ce}(0.4)-\mathrm{Ti}$ catalysts at $270{ }^{\circ} \mathrm{C}$ under different GHSVs is shown in Figure 9. As shown in Figure 9a, the steady state NO conversion of $\mathrm{Fe}(0.2)-\mathrm{Ti}$ catalyst was $85 \%$ in the absence of $\mathrm{SO}_{2}$ with a GHSV of $90,000 \mathrm{~h}^{-1}$. The NO conversion gradually decreased to about $75 \%$ in $7.5 \mathrm{~h}$ after $200 \mathrm{ppm} \mathrm{SO}_{2}$ was introduced into the feed. And finally, $\mathrm{NO}$ conversion reached stability at about $74.4 \%$. For the $\mathrm{Fe}(0.2)-\mathrm{Ce}(0.4)-\mathrm{Ti}$ catalysts, the initial NO conversion was $98 \%$ and increased slightly within the first $1.5 \mathrm{~h}$ after $\mathrm{SO}_{2}$ was introduced. The $\mathrm{NO}$ conversion then decreased slightly and reached stability at $92 \%$ after $25 \mathrm{~h}$ of $\mathrm{SO}_{2}$ exposure. With a GHSV of $150,000 \mathrm{~h}^{-1}$ (at this GHSV value, NO conversion of catalysts was no more than $80 \%$ at $270{ }^{\circ} \mathrm{C}$ ), $\mathrm{NO}$ conversion of both catalysts exhibited a further decrease in the presence of $200 \mathrm{ppm} \mathrm{SO}_{2}$, which is shown in Figure 9b. Compared to that of $\mathrm{Fe}(0.2)-\mathrm{Ti}$ catalyst, the loss of activity for $\mathrm{Fe}(0.2)-\mathrm{Ce}(0.4)-\mathrm{Ti}$ catalyst was less under different GHSVs and the NO conversion still exceeded $92 \%$ with $25 \mathrm{~h}, 200 \mathrm{ppm}$ $\mathrm{SO}_{2}$ treatment with a GHSV of $90,000 \mathrm{~h}^{-1}$, suggesting that the $\mathrm{Fe}(0.2)-\mathrm{Ce}(0.4)-$ Ti catalyst had better tolerance to $\mathrm{SO}_{2}$ after Ce doping.
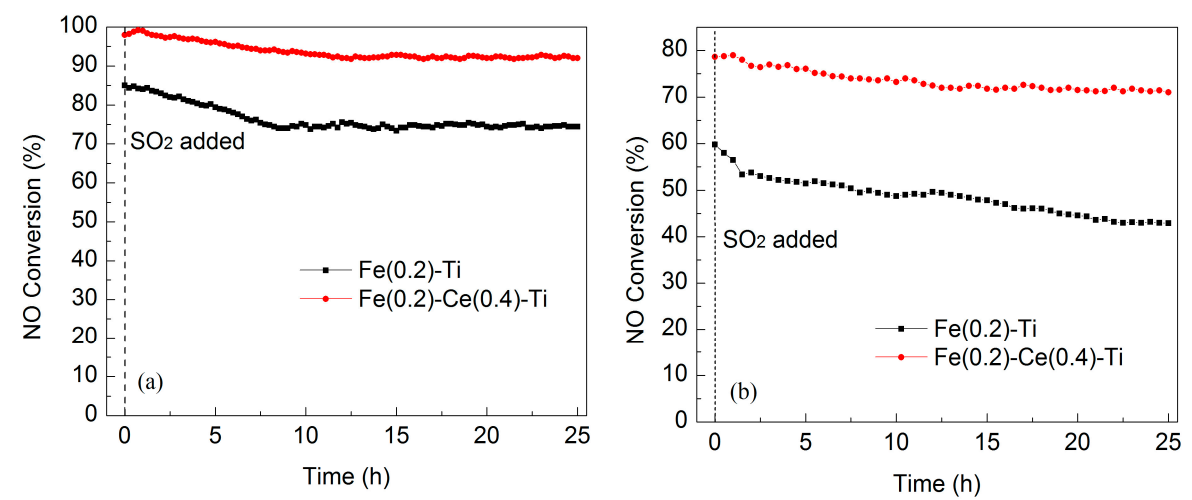

Figure 9. $\mathrm{NO}$ conversion of the $\mathrm{Fe}(0.2)-\mathrm{Ti}$ and $\mathrm{Fe}(0.2)-\mathrm{Ce}(0.4)-\mathrm{Ti}$ catalysts in the presence of $\mathrm{SO}_{2}$ at $270{ }^{\circ} \mathrm{C}$ under different GHSVs: (a) GHSV $=90,000 \mathrm{~h}^{-1}$ and (b) GHSV $=150,000 \mathrm{~h}^{-1}$. Reaction conditions: $[\mathrm{NO}]=\left[\mathrm{NH}_{3}\right]=500 \mathrm{ppm},\left[\mathrm{SO}_{2}\right]=200 \mathrm{ppm},\left[\mathrm{O}_{2}\right]=5$ vol. $\%, \mathrm{~N}_{2}$ balance. 
The effect of $\mathrm{H}_{2} \mathrm{O}$ and the synergistic effect of $\mathrm{H}_{2} \mathrm{O}$ and $\mathrm{SO}_{2}$ on catalytic activity of $\mathrm{Fe}(0.2)-\mathrm{Ce}(0.4)-\mathrm{Ti}$ catalysts with a GHSV of $90,000 \mathrm{~h}^{-1}$ at $270{ }^{\circ} \mathrm{C}$ were investigated and the results are shown in Figure 10. Before the $\mathrm{H}_{2} \mathrm{O}$ was added, the SCR reaction had stabilized for $0.5 \mathrm{~h}$ at $270{ }^{\circ} \mathrm{C}$. When 5 vol. $\% \mathrm{H}_{2} \mathrm{O}$ was introduced into the reactant gases, $\mathrm{NO}$ conversion gradually decreased to about $94 \%$ from its original level and then it almost kept stable. After $\mathrm{H}_{2} \mathrm{O}$ was cut off, $\mathrm{NO}$ conversion basically restored to $96.3 \%$, which was nearly its original level. This indicated the $\mathrm{Fe}(0.2)-\mathrm{Ce}(0.4)-\mathrm{Ti}$ catalysts exhibited good resistance to $\mathrm{H}_{2} \mathrm{O}$ at $270{ }^{\circ} \mathrm{C}$ and the inhibiting effect of $\mathrm{H}_{2} \mathrm{O}$ on catalysts activity was reversible. When $200 \mathrm{ppm} \mathrm{SO}$ and 5 vol. $\% \mathrm{H}_{2} \mathrm{O}$ were simultaneously introduced into the reactant gases at $270{ }^{\circ} \mathrm{C}$, the NO conversion slowly decreased to about $90 \%$ in about $2 \mathrm{~h}$ and then it nearly stayed at this level. When $\mathrm{SO}_{2}$ and $\mathrm{H}_{2} \mathrm{O}$ were removed, the $\mathrm{NO}$ conversion showed some increase but still could not reach its original level, which indicated such effect was irreversible. The reasons for this may be due to the fact that the competitive adsorption between $\mathrm{H}_{2} \mathrm{O}$ and reaction gases on active sites may happen, which would lead to the decrease of catalyst activity. When $\mathrm{H}_{2} \mathrm{O}$ was cut off, the effect was basically over and the $\mathrm{NO}$ conversion could return to its original level. When $\mathrm{H}_{2} \mathrm{O}$ and $\mathrm{SO}_{2}$ were simultaneously added, some sulfate species may be formed on the catalysts' surface in the presence of $\mathrm{H}_{2} \mathrm{O}$ and $\mathrm{SO}_{2}$, which would indirectly or directly decrease the catalysts' activity to some extent. The most important observation was that this effect could not be eliminated thoroughly even if the $\mathrm{H}_{2} \mathrm{O}$ and $\mathrm{SO}_{2}$ were removed.

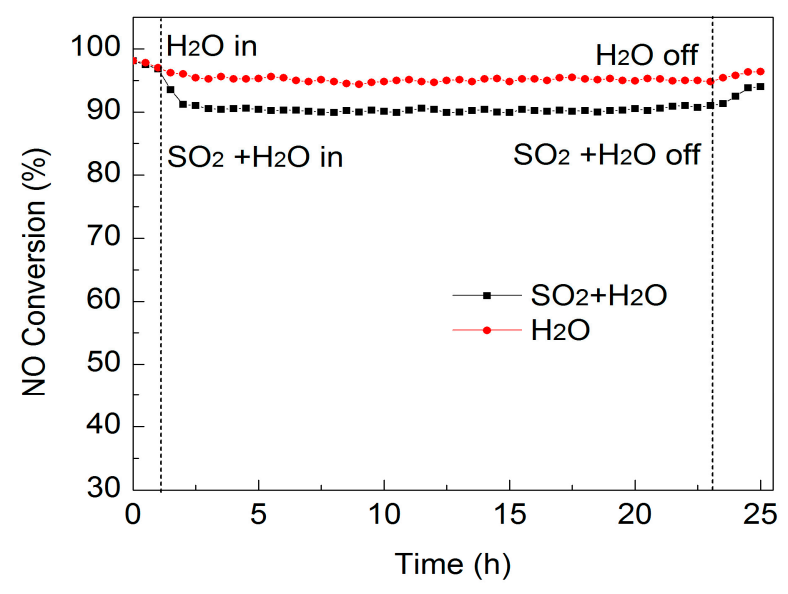

Figure 10. Effect of $\mathrm{H}_{2} \mathrm{O}$ and $\mathrm{SO}_{2}$ on $\mathrm{NO}$ conversion over $\mathrm{Fe}(0.2)-\mathrm{Ce}(0.4)-\mathrm{Ti}$ catalyst at $270{ }^{\circ} \mathrm{C}$. Reaction conditions: $[\mathrm{NO}]=\left[\mathrm{NH}_{3}\right]=500 \mathrm{ppm},\left[\mathrm{SO}_{2}\right]=200 \mathrm{ppm}$ (when used), $\left[\mathrm{H}_{2} \mathrm{O}\right]=5$ vol. \% (when used), $\left[\mathrm{O}_{2}\right]=5 \%, \mathrm{~N}_{2}$ balance, and GHSV $=90,000 \mathrm{~h}^{-1}$.

Thermogravimetric analysis (TGA) was used to investigate the surface species of the sample catalysts. The TGA spectra of the fresh and used $\mathrm{Fe}(0.2)-\mathrm{Ti}$ and $\mathrm{Fe}(0.2)-\mathrm{Ce}(0.4)-\mathrm{Ti}$ catalysts are shown in Figure 11. Compared to that of fresh catalysts, which only showed one instance of weight loss due to the release of water, the weight loss of used $\mathrm{Fe}(0.2)-\mathrm{Ti}$ and $\mathrm{Fe}(0.2)-\mathrm{Ce}(0.4)-\mathrm{Ti}$ catalysts were both divisible into three steps where two new weight loss instances were observed at higher temperatures. Step I appeared between room temperature and $250{ }^{\circ} \mathrm{C}$ due to the physical desorption of water [34,35]; Step II was observed from 250 to $470{ }^{\circ} \mathrm{C}$ and corresponds to the decomposition of ammonium sulfate formed during $\mathrm{SCR}$ reaction after $\mathrm{SO}_{2}$ addition on the catalyst surface [11,36]. The last step, above $470{ }^{\circ} \mathrm{C}$, may have been the decomposition of metal sulfates during the heating process $[11,37,38]$. TGA results clearly indicated that sulfate species were formed on the catalyst surface. 

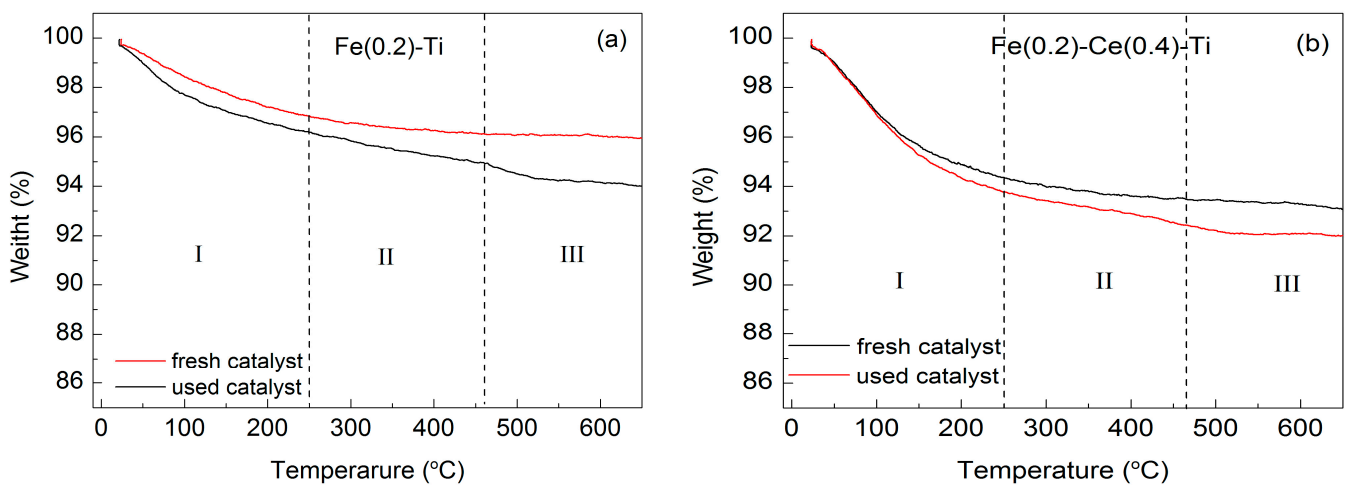

Figure 11. Thermogravimetric analysis (TGA) spectra of the fresh and used catalyst (a) Fe(0.2)-Ti and (b) $\mathrm{Fe}(0.2)-\mathrm{Ce}(0.4)-\mathrm{Ti}$.

FT-IR analysis provided further evidence for sulfate species formation; the FT-IR spectra of the fresh and used $\mathrm{Fe}(0.2)-\mathrm{Ti}$ and $\mathrm{Fe}(0.2)-\mathrm{Ce}(0.4)-\mathrm{Ti}$ catalysts are displayed in Figure 12. In comparison with the fresh catalysts, the used $\mathrm{Fe}(0.2)-\mathrm{Ti}$ and $\mathrm{Fe}(0.2)-\mathrm{Ce}(0.4)-\mathrm{Ti}$ catalysts exhibited new bands at $1410,1403,1087,1040$, and $980 \mathrm{~cm}^{-1}$. The strong bands at 1410 and $1403 \mathrm{~cm}^{-1}$ were assigned to $\mathrm{NH}_{4}{ }^{+}$ species [37], while the bands at 1087, 1040, and $980 \mathrm{~cm}^{-1}$ were due to $\mathrm{SO}_{4}{ }^{2-}$ ions [34,39,40]. These results were consistent with TGA analysis, which likewise indicated that sulfates species were formed on the catalyst surface.
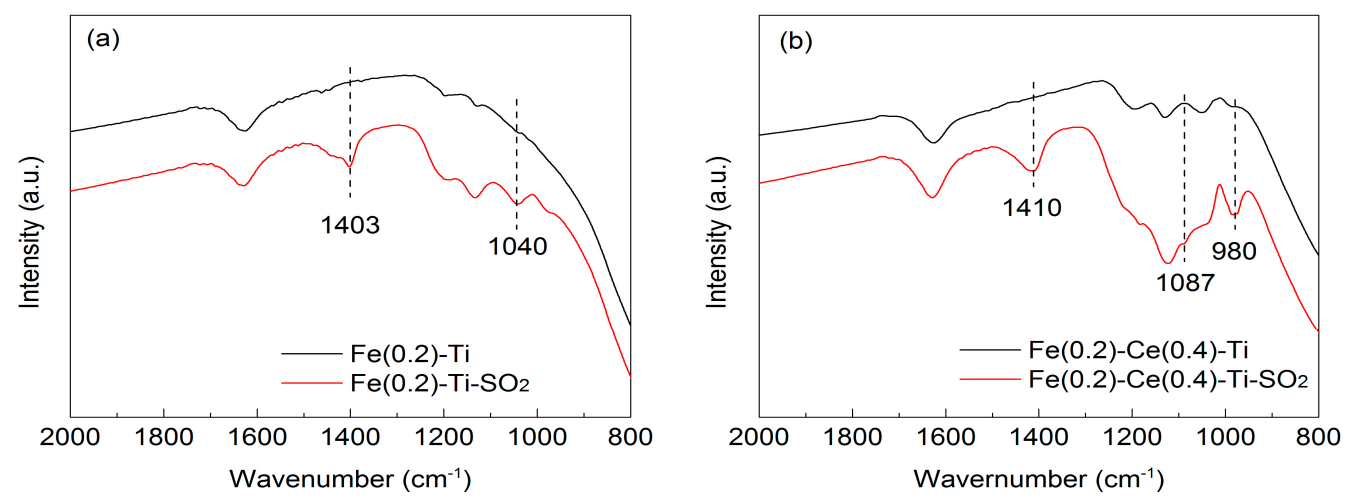

Figure 12. FT-IR spectra of the fresh and used catalyst: (a) Fe(0.2)-Ti and (b) Fe(0.2)-Ce(0.4)-Ti.

Based on the results of TGA and FT-IR, the decrease of catalysts' activity had two likely causes: (1) the ammonium sulfate formed during the reaction was deposited on the catalyst surface and covered the active sites, blocking the active channels of the catalyst; and (2) the active components were sulfated by $\mathrm{SO}_{2}$, rendering them unable to generate effective intermediate species and thus inhibiting the $S C R$ reaction $[38,41]$.

\section{Materials and Methods}

\subsection{Catalysts Preparation}

The Ce-doped Fe-Ti catalysts were prepared via co-precipitation method. First, $2.68 \mathrm{~g}$ $\mathrm{Fe}\left(\mathrm{NO}_{3}\right)_{3} \cdot 9 \mathrm{H}_{2} \mathrm{O}$ (Aladdin, Shanghai, China), $5.78 \mathrm{~g} \mathrm{Ce}\left(\mathrm{NO}_{3}\right)_{3} \cdot 6 \mathrm{H}_{2} \mathrm{O}$ (Aladdin, Shanghai, China), and $8 \mathrm{~g} \mathrm{Ti}\left(\mathrm{SO}_{4}\right)_{2}$ (Sinopharm, Shanghai, China) were added to a $150 \mathrm{~mL}$ beaker containing $60 \mathrm{~mL}$ deionized water, and the solution was stirred for $30 \mathrm{~min}$. Ammonia solution (25\%, AR, Sinopharm, Shanghai, China) was gradually added with continuous stirring until the $\mathrm{pH}$ reached 10 , followed by stirring for another $1 \mathrm{~h}$. The resulting precipitate was separated by filtration and washed thoroughly 
by centrifugation with deionized water, then the precipitate was collected and moved to an oven for drying at $120^{\circ} \mathrm{C}$ for $12 \mathrm{~h}$. The mixture was then ground and calcined in air at $500{ }^{\circ} \mathrm{C}$ for $4 \mathrm{~h}$. Finally, the catalysts were compressed into tablet form and sieved to 40-60 mesh for testing and analysis. For convenience, the first catalyst was denoted as $\mathrm{Fe}(0.2)-\mathrm{Ce}(0.4)-\mathrm{Ti}$. Catalysts $\mathrm{Fe}(0.02)-\mathrm{Ti}$, $\mathrm{Fe}(0.05)-\mathrm{Ti}$, $\mathrm{Fe}(0.1)-\mathrm{Ti}, \mathrm{Fe}(0.2)-\mathrm{Ti}, \mathrm{Fe}(0.4)-\mathrm{Ti}, \mathrm{Ce}(0.4)-\mathrm{Ti}, \mathrm{Fe}(0.2)-\mathrm{Ce}(0.02)-\mathrm{Ti}, \mathrm{Fe}(0.2)-\mathrm{Ce}(0.05)-\mathrm{Ti}, \mathrm{Fe}(0.2)-\mathrm{Ce}(0.2)-\mathrm{Ti}$, and $\mathrm{Fe}(0.2)-\mathrm{Ce}(0.8)-\mathrm{Ti}$ were fabricated using the same method. The number in brackets represents the $\mathrm{Fe} / \mathrm{Ti}$ and $\mathrm{Ce} / \mathrm{Ti}$ molar ratio, respectively.

\subsection{Catalysts Characterizations}

The specific area, pore volume, and pore size distribution of the catalysts were measured according to $\mathrm{N}_{2}$ adsorption at $77 \mathrm{~K}$ by BET method in a Micrometrics ASAP-2020 analyzer (Micromeritics, Norcross, GA, USA). About $100 \mathrm{mg}$ catalyst samples were used after pretreatment in $30{ }^{\circ} \mathrm{C}$ for $4 \mathrm{~h}$ in a $\mathrm{N}_{2} / \mathrm{He}$ mixture.

XRD analysis was carried out on a Philips X'pert Pro diffractometer (Philips, Eindhoven, Netherlands) with Ni-filtered $\mathrm{Cu} \mathrm{K} \alpha$ radiation $(0.15418 \mathrm{~nm})$. The $\mathrm{X}$-ray tube was operated at $40 \mathrm{kV}$ and $40 \mathrm{~mA}$.

$\mathrm{H}_{2}$-TPR experiments were conducted in a U-tube reactor (NJU, Nanjing, China) connected to a thermal conduction detector (TCD) using $\mathrm{Ar}-\mathrm{H}_{2}\left(7.0 \%\right.$ of $\mathrm{H}_{2}$ by volume, NJTQ, Nanjing, China) as the reducing mixture. Fifty milligram samples were used after pretreatment in $\mathrm{N}_{2}$ stream at $200^{\circ} \mathrm{C}$ for $1 \mathrm{~h}$ before reduction. The reduction of the samples was recorded form room temperature to $800^{\circ} \mathrm{C}$ at a heating rate of $10^{\circ} \mathrm{C} \cdot \mathrm{min}^{-1}$.

$\mathrm{NH}_{3}$-TPD experiments were carried out on a Micromeritics AutoChem II 2920 analyzer (Micromeritics, Atlanta, GA, USA); the $\mathrm{NH}_{3}$ desorption was detected with a thermal conductivity detector (TCD). As is typically required for TPD, about a $100 \mathrm{mg}$ sample was pretreated in $\mathrm{N}_{2}$ $\left(40 \mathrm{~mL} \cdot \mathrm{min}^{-1}\right)$ at $450{ }^{\circ} \mathrm{C}$ for $1 \mathrm{~h}$ and then treated with 1 vol. $\% \mathrm{NH}_{3}\left(10 \mathrm{~mL} \cdot \mathrm{min}^{-1}\right)$ at $100{ }^{\circ} \mathrm{C}$ for 1 $\mathrm{h}$ until saturation, then the sample was flushed with $\mathrm{N}_{2}$ at $100{ }^{\circ} \mathrm{C}$ for $1 \mathrm{~h}$. TPD operation was then completed by heating the sample from 100 to $500{ }^{\circ} \mathrm{C}$ at a heating rate of $10^{\circ} \mathrm{C} \cdot \mathrm{min}^{-1}$.

XPS measurements were read on a PHI 5000 Versa Probe system (ULVAC-PHI, Chigasaki, Japan) equipped with monochromatic $\mathrm{Al} \mathrm{K} \alpha$ radiation $(1486.6 \mathrm{eV})$. The samples were outgassed at room temperature in a ultrahigh-vacuum (UHV) chamber $\left(<5 \times 10^{-7} \mathrm{~Pa}\right)$ prior to data acquisition. The charging effect of samples was compensated for by $\mathrm{C} 1 \mathrm{~s}$ binding energy value of $284.6 \mathrm{eV}$ as an internal reference, which yielded BE values with an accuracy of $\pm 0.1 \mathrm{eV}$.

TGA measurement was conducted on a Pyris 1 TGA (PerKinElmer, Inc., Boston, MA, USA) instrument with a heating rate of $20^{\circ} \mathrm{C} \cdot \mathrm{min}^{-1}$ from room temperature to $650{ }^{\circ} \mathrm{C}$, and FT-IR spectra were recorded in the range of $400-4000 \mathrm{~cm}^{-1}$ on a Nicolet NEXUS870 spectrometer (Nicolet Instruments Inc., Madison, WI, USA).

\subsection{Catalytic Activity Measurements}

The catalytic activity of the catalysts were measured in a fixed-bed quartz reactor tube with $100 \mathrm{mg}$

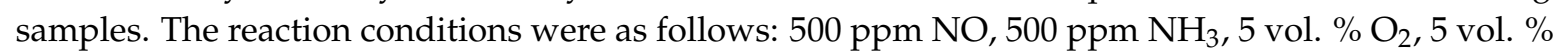
$\mathrm{H}_{2} \mathrm{O}$ (when used) and $200 \mathrm{ppm} \mathrm{SO}$ (when used) with balance $\mathrm{N}_{2}$, and gas flow rate of $100 \mathrm{~mL} \cdot \mathrm{min}^{-1}$. Before catalytic activity measurement, the catalysts were pretreated in a high-purity $\mathrm{N}_{2}$ stream at $200{ }^{\circ} \mathrm{C}$ for $1 \mathrm{~h}$ and cooled to room temperature. Reaction gases were introduced into the reactor until the catalysts were saturated, then catalytic activity measurements were recorded at different temperatures. All the data were obtained with an online Thermofisher IS10 FT-IR spectrometer (Thermo Fisher Scientific, Madison, WI, USA) equipped with a gas cell (250 $\mathrm{mL}$ volume) once the SCR reaction reached a steady state. 
The NO conversion was calculated by the following equation:

$$
\text { NO Conversion }=\frac{N O_{\text {in }}-N O_{\text {out }}}{N O_{\text {in }}} \times 100 \%
$$

where $N O_{\text {in }}$ and $N O_{\text {out }}$ are the inlet and outlet $\mathrm{NO}$ concentrations of the reactor, respectively.

\section{Conclusions}

In this study, we found that Ce doping can markedly enhance the catalytic activity and $\mathrm{SO}_{2}$-resistance of $\mathrm{Fe}-\mathrm{Ti}$ catalysts. The $\mathrm{Fe}(0.2)-\mathrm{Ce}(0.4)-\mathrm{Ti}$ catalyst exhibited more than $94 \% \mathrm{NO}$ conversion in a wide temperature range $\left(240-360^{\circ} \mathrm{C}\right)$ and obtained $92 \% \mathrm{NO}$ conversion in the presence of $200 \mathrm{ppm} \mathrm{SO}$ at $270{ }^{\circ} \mathrm{C}$ for $25 \mathrm{~h}$. The reasons for the superior catalytic activity we observed were as follows.

(1) The $\mathrm{Fe}(0.2)-\mathrm{Ce}(0.4)-\mathrm{Ti}$ catalyst prepared via co-precipitation had better texture compared to than $\mathrm{Fe}(0.2)-\mathrm{Ti}$ catalyst, including high surface area and high dispersion of active components on the catalyst surface.

(2) Doping Ce into Fe(0.2)-Ti catalyst improved its redox ability and greatly increased the amount of acid sites on the surface.

(3) As Ce load increased, the proportion of $\mathrm{Fe}^{3+}$ and $\mathrm{Ce}^{3+}$ decreased while the content of surface-adsorbed oxygen increased, all due to the interaction between Fe and Ce species.

(4) The decrease of catalyst activity caused by $\mathrm{SO}_{2}$ was likely due to the deposition of ammonium sulfate and the sulfation of active components during the SCR reaction.

Acknowledgments: This work was supported by the National High Technology Research and Development Program of China (863 Program) (2015AA03A401), and the National Natural Science Foundation of China (51276039, 21573105), and the Fundamental Research Funds for the Central Universities (020514380020, 020514380030), and Postdoctoral Science Foundation of Jiangsu Province, China (1501033A).

Author Contributions: X.W. conceived and designed the experiments; X.W. performed the experiments; L.Z., S.W., W.Z., S.Y. and Y.S. gave technical support and conceptual advice; X.W. wrote the paper; X.W. and L.D. revised the paper.

Conflicts of Interest: The authors declare no conflict of interest.

\section{References}

1. Yang, R.; Huang, H.F.; Chen, Y.J;; Zhang, X.X.; Lu, H.F. Performance of Cr-doped vanadia/titania catalysts for low-temperature selective catalytic reduction of $\mathrm{NO}_{x}$ with $\mathrm{NH}_{3}$. Chin. J. Catal. 2015, 36, 1256-1262. [CrossRef]

2. Yi, T.; Zhang, Y.B.; Li, J.W.; Yang, X.G. Promotional effect of $\mathrm{H}_{3} \mathrm{PO}_{4}$ on ceria catalyst for selective catalytic reduction of $\mathrm{NO}$ by $\mathrm{NH}_{3}$. Chin. J. Catal. 2016, 37, 300-307. [CrossRef]

3. Thirupathi, B.; Smirniotis, P.G. Nickel-doped $\mathrm{Mn} / \mathrm{TiO}_{2}$ as an efficient catalyst for the low-temperature SCR of $\mathrm{NO}$ with $\mathrm{NH}_{3}$ : Catalytic evaluation and characterizations. J. Catal. 2012, 288, 74-83. [CrossRef]

4. Jiang, S.Y.; Zhou, R.X. Ce doping effect on performance of the $\mathrm{Fe} / \beta$ catalyst for $\mathrm{NO}_{x}$ reduction by $\mathrm{NH}_{3}$. Fuel Process. Technol. 2015, 133, 220-226. [CrossRef]

5. Feng, B.J.; Wang, Z.; Sun, Y.Y.; Zhan, C.H.; Tang, S.F.; Li, X.B.; Huang, X. Size controlled ZSM-5 on the structure and performance of Fe catalyst in the selective catalytic reduction of $\mathrm{NO}_{x}$ with $\mathrm{NH}_{3}$. Catal. Commun. 2016, 80, 20-23. [CrossRef]

6. Zhu, L.; Qu, H.X.; Zhang, L.; Zhou, Q.W. Direct synthesis, characterization and catalytic performance of Al-Fe-SBA-15 materials in selective catalytic reduction of $\mathrm{NO}$ with $\mathrm{NH}_{3}$. Catal. Commun. 2016, 73, 118-122. [CrossRef]

7. Putluru, S.S.R.; Schill, L.; Jensen, A.D.; Siret, B.; Tabaries, F.; Fehrmann, R. $\mathrm{Mn} / \mathrm{TiO}_{2}$ and $\mathrm{Mn}-\mathrm{Fe} / \mathrm{TiO}_{2}$ catalysts synthesized by deposition precipitation-promising for selective catalytic reduction of $\mathrm{NO}$ with $\mathrm{NH}_{3}$ at low temperatures. Appl. Catal. B 2015, 165, 628-635. [CrossRef] 
8. Qi, G.S.; Yang, R.T. Low-temperature selective catalytic reduction of $\mathrm{NO}$ with $\mathrm{NH}_{3}$ over iron and manganese oxides supported on titania. Appl. Catal. B 2003, 44, 217-225. [CrossRef]

9. Zhou, G.Y.; Zhong, B.C.; Wang, W.H.; Guan, X.J.; Huang, B.C.; Ye, D.Q.; Wu, H.J. In situ DRIFTS study of $\mathrm{NO}$ reduction by $\mathrm{NH}_{3}$ over Fe-Ce-Mn/ZSM-5 catalysts. Catal. Today 2011, 175, 157-163. [CrossRef]

10. Zhang, J.; Qu, H.X. Low-temperature selective catalytic reduction of $\mathrm{NO}_{x}$ with $\mathrm{NH}_{3}$ over Fe-Cu mixed oxide/ZSM-5 catalysts containing $\mathrm{Fe}_{2} \mathrm{CuO}_{4}$ phase. Res. Chem. Intermed. 2015, 41, 4961-4975. [CrossRef]

11. Wang, X.B.; Gui, K.T. $\mathrm{Fe}_{2} \mathrm{O}_{3}$ particles as superior catalysts for low temperature selective catalytic reduction of NO with $\mathrm{NH}_{3}$. J. Environ. Sci. 2013, 25, 2469-2475. [CrossRef]

12. Shan, W.B.; Liu, F.D.; Yu, Y.B.; He, H. The use of ceria for the selective catalytic reduction of $\mathrm{NO}_{x}$ with $\mathrm{NH}_{3}$. Chin. J. Catal. 2014, 35, 1251-1259. [CrossRef]

13. Shen, B.X.; Wang, F.M.; Liu, T. Homogeneous $\mathrm{MnO}_{x}-\mathrm{CeO}_{2}$ pellets prepared by a one-step hydrolysis process for low-temperature $\mathrm{NH}_{3}$-SCR. Powder Technol. 2014, 253, 152-157. [CrossRef]

14. Shen, B.X.; Yao, Y.; Ma, H.Q.; Liu, T. Ceria modified $\mathrm{MnO}_{x} / \mathrm{TiO}_{2}$-pillared clays catalysts for the selective catalytic reduction of $\mathrm{NO}$ with $\mathrm{NH}_{3}$ at low temperature. Chin. J. Catal. 2011, 32, 1803-1811. [CrossRef]

15. Shen, B.X.; Liu, T.; Zhao, N.; Yang, X.Y.; Deng, L.D. Iron-doped Mn-Ce/ $\mathrm{TiO}_{2}$ catalyst for low temperature selective catalytic reduction of $\mathrm{NO}$ with $\mathrm{NH}_{3}$. J. Environ. Sci. 2010, 22, 1447-1454. [CrossRef]

16. Zhu, L.; Zhang, L.; Qu, H.X.; Zhong, Q. A study on chemisorbed oxygen and reaction process of Fe-CuO ${ }_{x} / Z S M-5$ via ultrasonic impregnation method for low-temperature $\mathrm{NH}_{3}$-SCR. J. Mol. Catal. A 2015, 409, 207-215. [CrossRef]

17. Peng, Y.; Yu, W.W.; Su, W.K.; Huang, X.; Li, J.H. An experimental and DFT study of the adsorption and oxidation of $\mathrm{NH}_{3}$ on a $\mathrm{CeO}_{2}$ catalyst modified by Fe, Mn, La and Y. Catal. Today 2015, 242, 300-307. [CrossRef]

18. Li, J.; Jia, L.W.; Jin, W.Y.; Xia, F.; Wang, J.M. Effects of Ce-doping on the structure and $\mathrm{NH}_{3}-\mathrm{SCR}$ activity of Fe/Beta catalyst. Rare Metal Mater. Eng. 2015, 44, 1612-1616.

19. Shu, Y.; Sun, H.; Quan, X.; Chen, S. Enhancement of catalytic activity over the iron-modified Ce/ $\mathrm{TiO}_{2}$ catalyst for selective catalytic reduction of $\mathrm{NO}_{x}$ with ammonia. J. Phys. Chem. C 2012, 116, 25319-25327. [CrossRef]

20. Long, R.Q.; Yang, R.T. Temperature-programmed desorption/surface Reaction (TPD/TPSR) study of Fe-exchanged ZSM-5 for selective catalytic reduction of nitric oxide by ammonia. J. Catal. 2001, 198, 20-28. [CrossRef]

21. Koebel, M.; Elsener, M.; Madia, G. Reaction pathways in the selective catalytic reduction process with NO and $\mathrm{NO}_{2}$ at low temperatures. Ind. Eng. Chem. Res. 2001, 40, 52-59. [CrossRef]

22. Romero-Sáez, M.; Divakar, D.; Aranzabal, A.; González-Velasco, J.R.; González-Marcos, J.A. Catalytic oxidation of trichloroethylene over Fe-ZSM-5: Influence of the preparation method on the iron species and the catalytic behavior. Appl. Catal. B 2016, 180, 210-218. [CrossRef]

23. Cao, F.; Su, S.; Xiang, J.; Wang, P.Y.; Hu, S.; Sun, L.S.; Zhang, A.C. The activity and mechanism study of Fe-Mn-Ce $/ \gamma-\mathrm{Al}_{2} \mathrm{O}_{3}$ catalyst for low temperature selective catalytic reduction of $\mathrm{NO}$ with $\mathrm{NH}_{3}$. Fuel 2015, 139, 232-239. [CrossRef]

24. Wan, Q.; Duan, L.; He, K.B.; Li, J.H. Removal of gaseous elemental mercury over a $\mathrm{CeO}_{2}-\mathrm{WO}_{3} / \mathrm{TiO}_{2}$ nanocomposite in simulated coal-fired flue gas. Chem. Eng. J. 2011, 170, 512-517. [CrossRef]

25. Yao, X.J.; Xiong, Y.; Zou, W.; Zhang, L.; Wu, S.G.; Dong, X.; Gao, F.; Deng, Y.; Tang, C.J.; Chen, Z.; et al. Correlation between the physicochemical properties and catalytic performances of $\mathrm{Ce}_{x} \mathrm{Sn}_{1-x} \mathrm{O}_{2}$ mixed oxides for NO reduction by CO. Appl. Catal. B 2014, 144, 152-165. [CrossRef]

26. Zhang, L.; Zou, W.X.; Ma, K.L.; Cao, Y.; Xiong, Y.; Wu, S.G.; Tang, C.J.; Gao, F.; Dong, L. Sulfated temperature effects on the catalytic activity of $\mathrm{CeO}_{2}$ in $\mathrm{NH}_{3}$-selective catalytic reduction conditions. J. Phys. Chem. C 2015, 119, 1155-1163. [CrossRef]

27. Zhang, X.P.; Shen, B.X.; Wang, K.; Chen, J.H. A contrastive study of the introduction of cobalt as a modifier for active components and supports of catalysts for $\mathrm{NH}_{3}$-SCR. J. Ind. Eng. Chem. 2013, 19, 1272-1279. [CrossRef]

28. Wu, S.G.; Zhang, L.; Wang, X.B.; Zou, W.X.; Cao, Y.; Sun, J.F.; Tang, C.J.; Gao, F.; Deng, Y.; Dong, L. Synthesis, characterization and catalytic performance of $\mathrm{FeMnTiO}_{x}$ mixed oxides catalyst prepared by a CTAB-assisted process for mid-low temperature $\mathrm{NH}_{3}$-SCR. Appl. Catal. A 2015, 505, 235-242. [CrossRef]

29. Zhang, L.; Li, L.L.; Cao, Y.; Xiong, Y.; Wu, S.G.; Sun, J.F.; Tang, C.J.; Gao, F.; Dong, L. Promotional effect of doping $\mathrm{SnO}_{2}$ into $\mathrm{TiO}_{2}$ over a $\mathrm{CeO}_{2} / \mathrm{TiO}_{2}$ catalyst for selective catalytic reduction of $\mathrm{NO}$ by $\mathrm{NH}_{3}$. Catal. Sci. Technol. 2015, 5, 2188-2196. [CrossRef] 
30. Shen, B.X.; Yao, Y.; Chen, J.H.; Zhang, X.P. Alkali metal deactivation of Mn-CeO $/$ Zr-delaminated-clay for the low-temperature selective catalytic reduction of $\mathrm{NO}_{x}$ with $\mathrm{NH}_{3}$. Microporous Mesoporous Mater. 2013, 180, 262-269.

31. Cheng, K.; Liu, J.; Zhang, T.; Li, J.M.; Zhao, Z.; Wei, Y.C.; Jiang, G.Y.; Duan, A.J. Effect of Ce doping of TiO 2 support on $\mathrm{NH}_{3}-\mathrm{SCR}$ activity over $\mathrm{V}_{2} \mathrm{O}_{5}-\mathrm{WO}_{3} / \mathrm{CeO}_{2}-\mathrm{TiO}_{2}$ catalyst. J. Environ. Sci. 2014, 26, 2106-2113. [CrossRef] [PubMed]

32. Wu, Z.B.; Jin, R.B.; Wang, H.Q.; Liu, Y. Effect of ceria doping on $\mathrm{SO}_{2}$ resistance of $\mathrm{Mn} / \mathrm{TiO}_{2}$ for selective catalytic reduction of $\mathrm{NO}$ with $\mathrm{NH}_{3}$ at low temperature. Catal. Commun. 2009, 10, 935-939. [CrossRef]

33. Gu, T.T.; Liu, Y.; Weng, X.L.; Wang, H.Q.; Wu, Z.B. The enhanced performance of ceria with surface sulfation for selective catalytic reduction of $\mathrm{NO}$ by $\mathrm{NH}_{3}$. Catal. Commun. 2010, 12, 310-313. [CrossRef]

34. Zhang, Q.L.; Zhang, J.H.; Song, Z.X.; Ning, P.; Li, H.; Liu, X. A novel and environmentally friendly $\mathrm{SO}_{4}{ }^{2-} / \mathrm{CeO}_{2}$ catalyst for the selective catalytic reduction of $\mathrm{NO}$ with $\mathrm{NH}_{3}$. J. Ind. Eng. Chem. 2016, 34, 165-171. [CrossRef]

35. Kumar, P.A.; Reddy, M.P.; Ju, L.K.; Hyun-Sook, B.; Phil, H.H. Low temperature propylene SCR of NO by copper alumina catalyst. J. Mol. Catal. A 2008, 291, 66-74. [CrossRef]

36. Shu, Y.; Aikebaier, T.; Quan, X.; Chen, S.; Yu, H.T. Selective catalytic reaction of $\mathrm{NO}_{x}$ with $\mathrm{NH}_{3}$ over $\mathrm{Ce}-\mathrm{Fe} / \mathrm{TiO}_{2}$-loaded wire-mesh honeycomb: Resistance to $\mathrm{SO}_{2}$ poisoning. Appl. Catal. B 2014, 150-151, 630-635. [CrossRef]

37. Huang, J.H.; Tong, Z.Q.; Huang, Y.; Zhang, J.F. Selective catalytic reduction of NO with $\mathrm{NH}_{3}$ at low temperatures over iron and manganese oxides supported on mesoporous silica. Appl. Catal. B 2008, 78, 309-314. [CrossRef]

38. Shen, B.X.; Zhang, X.P.; Ma, H.Q.; Yao, Y.; Liu, T. A comparative study of $\mathrm{Mn} / \mathrm{CeO}_{2}, \mathrm{Mn} / \mathrm{ZrO} 2$ and $\mathrm{Mn} / \mathrm{Ce}-\mathrm{ZrO}_{2}$ for low temperature selective catalytic reduction of $\mathrm{NO}$ with $\mathrm{NH}_{3}$ in the presence of $\mathrm{SO}_{2}$ and $\mathrm{H}_{2}$ O. J. Environ. Sci. 2013, 25, 791-800. [CrossRef]

39. Chang, H.Z.; Ma, L.; Yang, S.J.; Li, J.H.; Chen, L.; Wang, W.; Hao, J.M. Comparison of preparation methods for ceria catalyst and the effect of surface and bulk sulfates on its activity toward $\mathrm{NH}_{3}$-SCR. J. Hazard. Mater. 2013, 262, 782-788. [CrossRef] [PubMed]

40. Waqif, M.; Bazin, P.; Saur, O.; Lavalley, J.C.; Blanchard, G.; Touret, O. Study of ceria sulfation. Appl. Catal. B 1997, 11, 193-205. [CrossRef]

41. Yu, J.; Guo, F.; Wang, Y.L.; Zhu, J.H.; Liu, Y.Y.; Su, F.B.; Gao, S.Q.; Xu, G.W. Sulfur poisoning resistant mesoporous Mn-base catalyst for low-temperature SCR of $\mathrm{NO}$ with $\mathrm{NH}_{3}$. Appl. Catal. B 2010, 95, 160-168. [CrossRef]

(C) 2016 by the authors; licensee MDPI, Basel, Switzerland. This article is an open access article distributed under the terms and conditions of the Creative Commons Attribution (CC-BY) license (http://creativecommons.org/licenses/by/4.0/). 